Esta publicación cientifica en formato digital es continuidad de la revista impresa ISSN-Versión Impresa 0798-1406 / ISSN-Versión on line 2542-3185Depósito legal pp
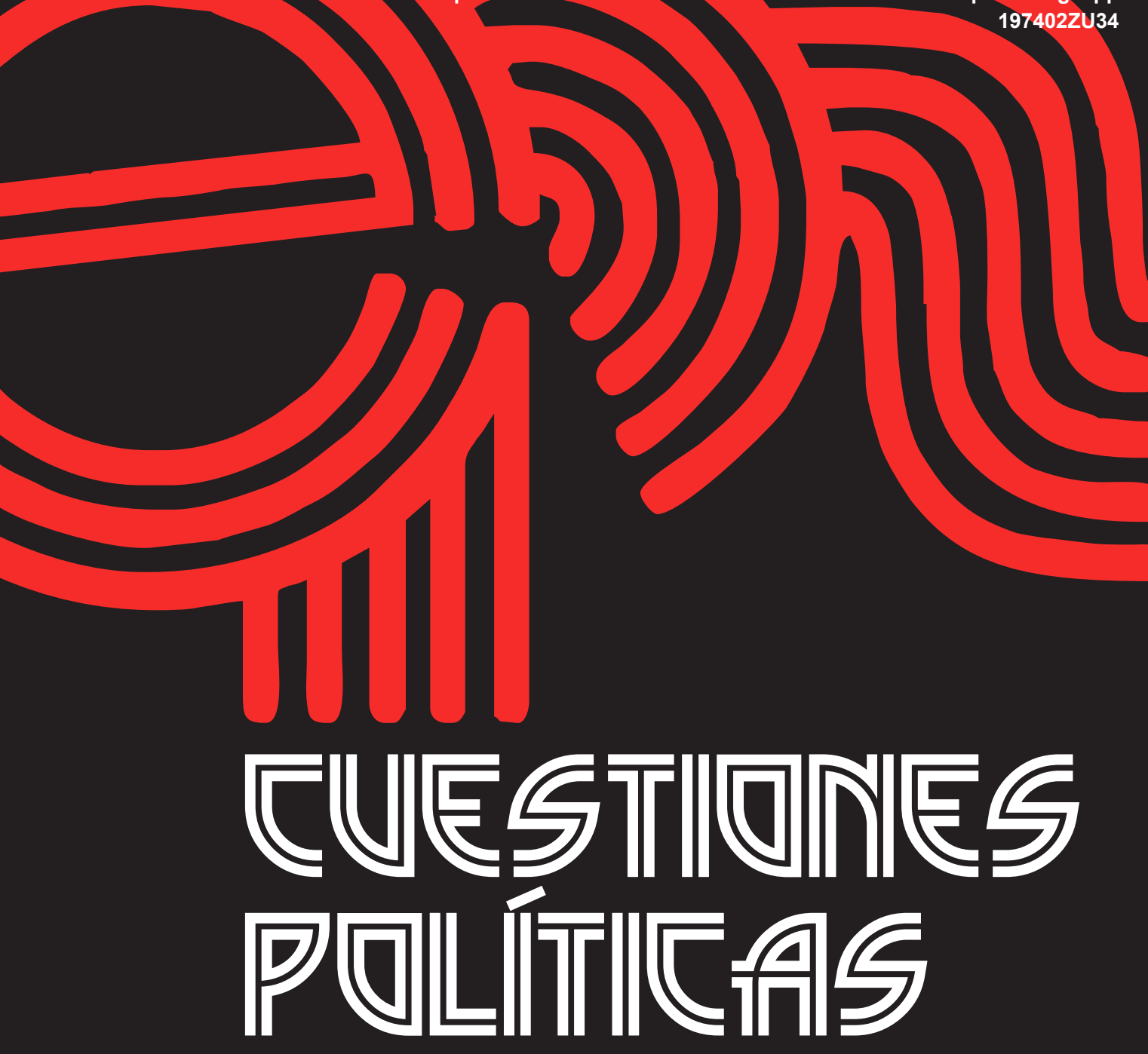

Instituto de Estudios Políticos y Derecho Público "Dr. Humberto J. La Roche" de la Facultad de Ciencias Jurídicas y Políticas de la Universidad del Zulia Maracaibo, Venezuela
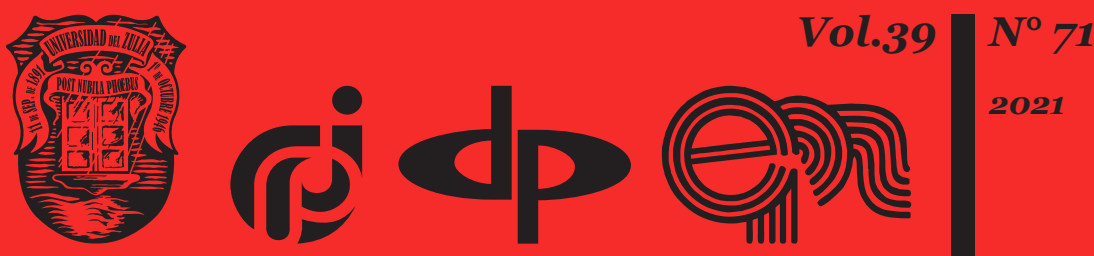


\title{
Criminal Liability for Providing Inaccurate Information about the Spread of the COVID-19 Epidemic
}

\author{
DOI: https://doi.org/10.46398/cuestpol.3971.12
}

\author{
Andrii A. Danylevskyi * \\ Mykhailo A. Akimov ** \\ Vladyslav I. Kutsenko *** \\ Oleksandr I. Savka **** \\ Tetiana Ye. Leonenko *****
}

\section{Abstract}

The aim of this study was to identify problems related to the establishment of criminal liability for providing inaccurate information about the spread of the Covid-19 epidemic, and propose the ways to solve them. To aim involved the following methods: systemic approach, descriptive statistics, comparative approach, descriptive analysis, pragmatic approach, and forecasting. The effectiveness of health authorities' response to outbreaks of diseases depends on the completeness and accuracy of the information disseminated. In fact, national legislations do not provide criminal liability for providing inaccurate information about the epidemiological situation in a pandemic. Therefore, there is a need to develop Interim Guidelines to ensure the accuracy of information on the epidemiological situation in a pandemic. A rule that criminalizes the provision of inaccurate information or the dissemination of inaccurate information about the incidence in an epidemic and/or pandemic, should be one of the rules on liability for crimes against national security, and should be punishable by imprisonment for a certain period and deprivation of the right to hold certain positions and engage in certain activities. This study is not exhaustive and opens up prospects for further research in this area.

* PhD in Law, Head of the Department of Criminal Law and Criminology, Donetsk Law Institute of the Ministry of Internal Affairs of Ukraine. ORCID ID: https://orcid.org/oooo-0002-9315-9381

** Candidate of Law, Associate Professor of Criminal Law Department, National Academy of Internal Affairs. ORCID ID: https://orcid.org/oooo-0001-7715-0259

*** Candidate of Economic, Associate Professor of Department of Civil and International Law, Law and Management Institute, Zaporizhzhia Polytechnic National University ORCID ID: https://orcid. org/oooo-0003-0878-9360

**** Candidate of Law, Head of the Department of Criminal Law and Procedure, Kyiv University of Law of the National Academy of Ukraine. ORCID ID: https://orcid.org/oooo-0oo2-1723-3412

***** Doctor of Law, Head of the Department of Criminal, Civil and International Law, Law and Management Institute, Zaporizhzhia Polytechnic National University. ORCID ID: https://orcid. org/oooo-0oo1-8466-7192 
Andrii A. Danylevskyi, Mykhailo A. Akimov, Vladyslav I. Kutsenko, Oleksandr I. Savka y Tetiana Ye. Leonenko

Keywords: pandemic; epidemic; inaccurate information; misinformation; criminal liability.

\section{Responsabilidad penal por proporcionar información inexacta sobre la propagación de la epidemia de Covid-19}

\section{Resumen}

El objetivo de este estudio fue identificar los problemas relacionados con el establecimiento de la responsabilidad penal por proporcionar información inexacta sobre la propagación de la epidemia Covid-19 y proponer las formas de solucionarlos. Involucró los siguientes métodos: enfoque sistémico, estadística descriptiva, comparación y comparación, análisis descriptivo, enfoque pragmático, pronóstico. La eficacia de la respuesta de las autoridades sanitarias a los brotes de determinadas enfermedades depende de la integridad y precisión de la información difundida. De hecho, las legislaciones nacionales no prevén responsabilidad penal por proporcionar información inexacta sobre la situación epidemiológica en una pandemia. Por lo tanto, es necesario desarrollar directrices provisionales para garantizar la precisión de la información sobre la situación epidemiológica en una pandemia. Una norma que tipifique como delito el suministro de información inexacta o la difusión de información inexacta sobre la incidencia de una epidemia y/o pandemia debería ser una de las normas sobre responsabilidad por delitos contra la seguridad nacional y debería ser punible con prisión por un período determinado y privación del derecho a ocupar determinados cargos y realizar determinadas actividades. Este estudio no es exhaustivo y abre perspectivas para futuras investigaciones en esta área.

Palabras clave: pandemia; epidemia; información inexacta; desinformación; responsabilidad penal.

\section{Introduction}

The years of 2020-2021 have become unprecedented in the history of mankind - everyone, regardless of place of residence or stay, was in danger due to the Covid-19 pandemic. The Covid-19 pandemic, which affected almost all countries of the world, caused significant changes in all spheres of public life. Several measures have been implemented in each country to stabilize the spread of coronavirus disease and stop the growth in the number of patients in the world. These measures consisted mainly in the 
restriction of certain spheres of life, which led to the problem of ensuring human rights and freedoms in pandemics (Kacper, 2020).

As a result, the vast majority of people have reconsidered their values, fundamental interests, their own rights and freedoms, the possibility and necessity of their restrictions in order to ensure them, and so on. The modern pandemic, like any dangerous phenomenon, has caused negative social changes. After all, these and similar phenomena in the world generate fear, paranoid moods in society, which in turn leads to an increased level of negative and dangerous manifestations in society (Freckelton, 2020).

These negative social manifestations have affected many spheres of life, and first of all, the sphere of protection and maintenance of human life and health in the rapid spread of Covid-19 and its various strains (Rajat, 2020; $\mathrm{Radu}, 2020$ ). In particular, against the background of the spread of a new viral disease, the number of violent crimes has increased rapidly, especially in the field of family relations (Bettinger-Lopezand and Bro, 2020); cybersecurity and information security crime has increased(Kovaleva et al., 2020); people's right to life (Maheshwari and Gautam, 2021) and other fundamental rights and freedoms (Abrusci et al., 2020) are violated; the number of crimes in the medical and health care sectors by both doctors (Alameer et al., 2021) and health workers (Ernesto D’Aloja et al., 2020) has increased, thus raising the issue of medical ethics during the pandemic (Bustan et al., 2021). Besides, there are frequent violations of quarantine restrictions and prohibitions (Kovalova, 2021) aimed at stabilizing the health situation and reducing the incidence in the world until overcoming the global pandemic. Of course, this negatively affects the level of public life both in individual countries and in the world.

But one of the biggest threats to protecting the population from the spread of the pandemic and protecting the right to life and health is the falsification of morbidity data and the spread of inaccurate statics. A pandemic is a phenomenon that is developing very rapidly, and the quality of counteraction to this phenomenon is based on the analysis of the latest data that can provide an answer about the sources, rates of spread, risks (Kacper, 2020; Li et al., 2020). The effectiveness of such activities depends on the data which must be reliable, complete and comprehensive in describing the situation (Barnert et al., 2020).

\section{Literature review}

Alarge number of recent studies deal with certain aspects of counteracting the spread of the Covid-19 virus in the world, ensuring the protection of the population from the spread of this disease, and overcoming the pandemic. Researchers and healthcare workers propose a number of measures to 
protect safety in a pandemic, and given these threats, the necessary step is to develop new security measures for all areas of public life, which are covered in the relevant sources.

The security of life, health of the population, other social spheres (economic, informational, medical, cybernetic, etc.) constitute the national security of individual states. That is why the vast majority of countries and international organizations are working to improve the legislation, which will provide additional guarantees of compliance in a pandemic. The issues of responsibility of states for offenses in the field of anti-pandemic activities and the use of international law resources (Quintana and Uriburu, 2020; Allahverdipour, 2020) for this purpose are currently being developed; special criminological research is carried out in the economic sphere in a pandemic (USA) (Friedrichs and Vegh Weis, 2021); the problems of criminal liability in a pandemic are studied, including liability for violations of anti-epidemic and sanitary rules in some countries and regions of the world (Ukraine (Kovalova, 2021), Syria (Roger and Layla, 2020) China (Roger and Layla, 2020), India (Dattaa et al., 2020) Bahrain (Bani-issa, 2021), Africa (Bani-issa, 2021).

One of the main directions, given the importance of obtaining accurate information, is to establish responsibility for providing official inaccurate information on the incidence of Covid-19 and disseminating inaccurate information about the epidemic - for the so-called infodemic in the global Covid-19 pandemic (Gorbatenko, 2021; Yirong, 2021). In particular, the impact of unreliable news and misinformation during a pandemic on both the epidemiological situation and other areas of social life is studied (Kacper, 2020); negative consequences of misinformation of the population through messages or stories about protection against Covid-19 (Hurford et al., 2021); modelling and forecasting of consequences of the failure to use standard data on Covid-19 is carried out (Ashrafi-Rizi and Zahra, 2020); the dangers of inaccurate messages are emphasized (Bratu, 2020; Minfin, 2021).

Despite the danger of providing inaccurate data on the state of the Covid-19 epidemic, both for the individual and for each country, the problem of liability, including criminal liability, for providing inaccurate information on the incidence rate remains unresolved. However, in the context of globalization and the need to join forces to overcome the pandemic in the world, appropriate standards must be developed at both national and international levels. So, this study is the first to raise the problem of criminal liability for providing inaccurate information about the spread of the Covid-19 epidemic in this formulation. 


\subsection{Aim}

Given the urgency of the study, the aim will be to identify a range of issues related to the establishment of criminal liability for providing inaccurate information about the spread of the Covid-19 epidemic, and ways to address them at the national and international levels. The aim involved the following objectives: determine the grounds for criminalizing the provision of inaccurate information on the Covid-19 epidemic situation and develop proposals for improving the legal regulation of criminal prosecution for this act.

\section{Methodology and methods}

This study was conducted in a clear sequence, following the stages of studying the issue based on the logic of the presentation of the material, in order to achieve the aim, set in the article and fulfil the objectives. The stages were the following: formulation of the range of issues and defining the scope of the study; search and selection of literature and other resources; selection and study of statistics; analysis of the material presented in selected resources and evaluation of the results of these studies; identification of unresolved problems of criminal liability for dissemination of inaccurate information about the spread of the Covid-19 epidemic; determining the aim of the article; drawing conclusions and making practical recommendations for solving the problems chosen for research; outlining prospects for further research in this area.

The study involved statistics on quantitative indicators of morbidity and mortality caused by Covid-19 by individual countries and regions of the world, as well as statistics on the dynamics of morbidity of Covid-19 in the world for 2020-2021; expert opinions on the inaccuracy of statistics on the level of morbidity and mortality caused by Covid-19 in individual countries and in the world. The provisions of international regulatory acts, which determine certain aspects of the procedure for information circulation in various sources, in particular on the Internet, were studied in order to identify gaps and make proposals for their elimination both in international provisions and in the national legislation of individual countries for holding liable for providing inaccurate information on the epidemiological situation in the context of the Covid-19 pandemic.

The legal framework of the study consisted of the provisions of international regulations, in particular the Council of Europe Convention for the Protection of Individuals with regard to Automatic Processing of Personal Data, 1981; UN Convention on Access to Information, Public Participation in Decision-Making and Access to Justice in Environmental 
Matters, 1998; Okinawa Charter on the Global Information Society 2000; and others. The national legislation of 10 countries was reviewed to analyse the provisions of national legislation that determine the responsibility for providing inaccurate information, including in the context of a pandemic on the incidence rate.

The study involved the following methods: the system approach was used to analyse the Covid-19 pandemic as a system of interrelated and interdependent measures of national and international health policy; descriptive statistics, which was used for processing, systematization and visual demonstration of basic statistical indicators on the incidence of Covid-19 in some countries and in the world in the form of tables; comparison was used to determine the dynamics of the Covid-19 epidemic in the world for 2020-2021; descriptive analysis was used to arrange, classify and summarize information on public danger and the consequences of info emic and the dissemination of unreliable news about the incidence of Covid-19; pragmatic approach to data collection and analysis, which was used to determine the main grounds for criminalization of illegal acts in the field of dissemination of inaccurate information about Covid-19; forecasting was used to develop proposals and recommendations for improving the legislation on the establishment of criminal liability for providing inaccurate information about the epidemiological situation.

\section{Results}

The effectiveness of health authorities' response to outbreaks depends on the completeness and accuracy of the information disseminated. This also applies to the dissemination of information about the epidemiological situation on the incidence of Covid-19. The world has been living in a pandemic for the last two years. This situation is far from over, as all measures taken during 2020-2021 aimed at stabilizing the epidemiological situation at all levels (national, regional, global) do not yet give the expected and desired result. Although there are certain periods of declining morbidity, the number of people who fell ill with Covid-19 and died as a result is constantly growing. This is clearly evidenced by official statistics (see Table 1 and Table 2).

Table 1. Data on the incidence of covid-19 (as of September 2021). (Worldometers, 2021).

\begin{tabular}{|l|l|l|l|l|}
\hline Country & Population & $\begin{array}{l}\text { Number of } \\
\text { patients }\end{array}$ & $\begin{array}{l}\text { Number of } \\
\text { recovered }\end{array}$ & $\begin{array}{l}\text { Number of } \\
\text { fatalities }\end{array}$ \\
\hline USA & $331,002,651$ & $42,799,907$ & $32,434,166$ & 690,714 \\
\hline India & $1,380,004,385$ & $33,417,390$ & $32,632,222$ & 444,563 \\
\hline
\end{tabular}




\begin{tabular}{|c|c|c|c|c|}
\hline Brasilia & $212,559,417$ & $21,102,536$ & $20,180,106$ & 589,744 \\
\hline $\begin{array}{l}\text { Great } \\
\text { Britain }\end{array}$ & $67,886,011$ & $73,71,301$ & $5,934,018$ & 134,983 \\
\hline $\begin{array}{l}\text { Russian } \\
\text { Federation }\end{array}$ & $145,934,462$ & $7,254,754$ & $6,485,264$ & 197,425 \\
\hline France & $65,273,511$ & $6,942,105$ & $6,612,898$ & 115,960 \\
\hline Turkey & $84,339,967$ & $6,794,700$ & $6,285,887$ & 61,140 \\
\hline Iran & $83,992,949$ & $5,396,013$ & $4,708,195$ & 116,436 \\
\hline Argentina & $45,195,774$ & $5,237,159$ & $5,090,449$ & 114,286 \\
\hline Spain & $46,754,778$ & $4,929,546$ & $4,633,527$ & 85,783 \\
\hline Italy & $60,461,826$ & 4,627,699 & $4,383,195$ & 13,233 \\
\hline Germany & $83,783,942$ & $4,139,009$ & $3,873,700$ & 93,517 \\
\hline $\begin{array}{l}\text { Republic of } \\
\text { Poland }\end{array}$ & $37,846,611$ & $2,897,395$ & $2,659,020$ & 75,487 \\
\hline SAR & $59,308,690$ & $2,877,063$ & $2,714,565$ & 85,952 \\
\hline Ukraine & $43,733,762$ & $2,344,398$ & $2,230,306$ & 54,829 \\
\hline $\begin{array}{l}\text { Czech } \\
\text { Republic }\end{array}$ & $10,708,981$ & $1,685,878$ & $1,650,292$ & 30,429 \\
\hline Japan & $126,476,461$ & $1,668,136$ & $1,564,097$ & 17,097 \\
\hline Canada & $37,742,154$ & $1,569,186$ & $1,497,434$ & 27,370 \\
\hline Israel & $8,655,535$ & $1,211,443$ & $1,122,876$ & 7,494 \\
\hline $\begin{array}{l}\text { Republic of } \\
\text { Kazakhstan }\end{array}$ & $18,776,707$ & 857,643 & 784,541 & 10,670 \\
\hline Switzerland & $8,654,622$ & 823,074 & 736,388 & 11,010 \\
\hline Georgia & $3,989,167$ & 593,763 & 558,042 & 8,498 \\
\hline $\begin{array}{l}\text { Republic of } \\
\text { Belarus }\end{array}$ & $9,449,323$ & 512,460 & 500,051 & 3,978 \\
\hline Norway & $5,421,241$ & 181,195 & 88,952 & 841 \\
\hline China & $1,439,323,776$ & 95,623 & 90,074 & 4,636 \\
\hline Australia & $25,499,884$ & 84,086 & 61,869 & 1,148 \\
\hline Luxemburg & 625,978 & 77,189 & 75,209 & 834 \\
\hline Singapore & $5,850,342$ & 75,783 & 69,614 & 59 \\
\hline Niger & $24,206,644$ & 5,951 & 5,685 & 201 \\
\hline San Marino & 33,931 & 5,388 & 5,240 & 90 \\
\hline $\begin{array}{l}\text { Total in } \\
\text { the world }\end{array}$ & $7,894,214,059$ & 228112671 & $204,762,776$ & $4,688,259$ \\
\hline
\end{tabular}


Andrii A. Danylevskyi, Mykhailo A. Akimov, Vladyslav I. Kutsenko, Oleksandr I. Savka y Tetiana Ye. Leonenko

Table 2. Incidence of Covid-19 by regions of the world (according to the WHO as of September 2021). (Global-data, 2021).

\begin{tabular}{|l|l|}
\hline Region & The number of Covid-19cases \\
\hline Americas & $87,430,315$ \\
\hline Europe & $67,977,169$ \\
\hline South-East Asia & $42,385,258$ \\
\hline Eastern Mediterranean & $15,377,433$ \\
\hline Western Pacific & $7,779,616$ \\
\hline Africa & $5,893,789$ \\
\hline
\end{tabular}

The dynamics of the pandemic throughout the time was wavy (and continues to be so): from a sharp increase in the number of patients with Covid-19 to a gradual significant reduction in the incidence. Depending on the season, the seasonal diseases, the number of mass events and the number of crowded places (the period of celebration of public and religious holidays, the beginning of studies in schools and universities, starting work after vacations, etc.), the incidence of Covid-19 is growing rapidly; the introduction of stricter quarantine measures, the state of emergency in some countries, the beginning of the period of holidays and vacations contributes to reducing the incidence rate (see Table 3).

Table 3. Dynamics of the Covid-19 pandemic (daily morbidity and mortality at the end of each month for 2020-2021).

(Worldometers, 2021).

\begin{tabular}{|l|l|l|}
\hline Date (month, year) & Incidence rate & Mortality rate \\
\hline January 2020 & $>2,000$ & n/a \\
\hline February 2020 & 3,000 & n/a \\
\hline March 2020 & 75,613 & 4,788 \\
\hline April 2020 & 89,843 & 6,389 \\
\hline May 2020 & 126,892 & 4,133 \\
\hline June 2020 & 183,598 & 5,756 \\
\hline July 2020 & 290,503 & 6,769 \\
\hline August 2020 & 250,654 & 4,864 \\
\hline September 2020 & 322,022 & 5,661 \\
\hline
\end{tabular}




\begin{tabular}{|l|l|l|}
\hline October 2020 & 504,382 & 6,935 \\
\hline November 2020 & 497,366 & 9,185 \\
\hline December 2020 & 735,218 & 14,067 \\
\hline January 2021 & 415,869 & 9,679 \\
\hline February 2021 & 320,446 & 6,638 \\
\hline March 2021 & 547,699 & 12,231 \\
\hline April 2021 & 875,901 & 14,671 \\
\hline May 2021 & 368,714 & 9,040 \\
\hline June 2021 & 398,202 & 8,840 \\
\hline July 2021 & 597,080 & 9,222 \\
\hline August 2021 & 538,833 & 9,581 \\
\hline September 2021 & 419,393 & 6,820 \\
\hline
\end{tabular}

Declines in the incidence of Covid-19 in the world in certain periods indicate that the methods introduced by states at the national level have been effective. Therefore, these measures were applied in a timely manner, which means that the information on the statistics was used correctly. With the onset of the pandemic, the relevant state authorities were forced to respond quickly to changes in the epidemiological dynamics at the national level.

The countries have introduced stricter measures to combat the spread of the disease, or there has been a weakening of anti-epidemic measures. These measures are introduced, changed and repealed based on statistics on the incidence rate. And in order to make the change in the effectiveness of anti-epidemic measures as effective as possible, the data on the number of people who fell ill, recovered or died corresponded to the real state of affairs. But, unfortunately, these data are not always real - they are often falsified to achieve one or another illegal goal.

For example, according to some data, the incidence of Covid-19 in Italy is 6 times higher than indicated in official statistics, and the real mortality it caused is 60\% higher than the official one (Corriere Della Sera, 2020). The official incidence of Covid-19 in Ukraine is also far from reality: it is noted that statistics are only 30\% of the actual number of cases (Interfax, 2020). German scholars have found that the actual number of Covid-19 cases is 10 times higher than official figures (Zdrav.Expert, 2021). It is also stated that the real mortality caused by Covid-19 in the Russian Federation is $72 \%$ higher than official figures. In India, the real number of deaths is 5-10 times 
Andrii A. Danylevskyi, Mykhailo A. Akimov, Vladyslav I. Kutsenko, Oleksandr I. Savka y Tetiana Ye. Leonenko

higher than the death rate reported in official statistics (DW, 2020). As for the general world statistics, it is also indicated that the real mortality rate caused by Covid-19 is $60 \%$ higher than the official data (Financical times, 2020).

The list of countries the official information on morbidity and mortality caused by Covid-19 of which is significantly different from the actual state of the epidemic can be continued. This situation with the provision of inaccurate information is disappointing.

Distortion of data on the incidence of Covid-19, in turn, entails a decrease in the effectiveness of counteracting its growth both at the level of individual states and at the global level. Thus, this state of affairs makes it almost impossible to overcome the pandemic in the world.

Such a situation necessitates measures to ensure the provision of accurate information. One of the effective measures is to bring a person who spreads false information to the most severe type of liability - criminal. However, national law enforcement agencies face the problem of the lack of a specific rule both in individual states and at the international level that would penalize misinformation in an emergency. Moreover, as the analysis of the legislation has shown, the criminal law of some countries does not even have a general rule that establishes responsibility for providing or disseminating inaccurate information as a threat to national security.

Criminal liability for misinformation as a crime against state interests is provided in China, Egypt, the United Arab Emirates, where misinformation is punishable by imprisonment for a term and a fine; disseminate false personal information about certain categories of persons under Canadian law; Denmark, Great Britain, Germany, India provides responsibility for disseminating inaccurate information on the Internet, social networks, etc. (HSDL, 2019). But the responsibility for providing inaccurate information and disseminating fake data on the Covid-19 epidemiological situation in these countries is not provided. Some countries, including Ukraine, do not provide criminal liability for disseminating inaccurate information at all.

A specific term - infodemic - is used in the article for the provision of inaccurate information or the dissemination of false data, which means the rapid spread of false news, usually in relation to the pandemic and its individual aspects. The term has come about recently, as this phenomenon spreads during the Covid-19 pandemic in the world.

The barrage of false information about Covid-19, some information, and data about this viral disease, which was often spread by government officials and the media, helped to undermine trust in the leaders of health care organizations and create obstacles to contain the pandemic in the world. This was caused by the statements of so-called experts, virologists, and other members of the public, who downplayed the danger of Covid-19 
and spread rumors about the origin of the virus, false information about its course and consequences. The most common such news includes the socalled conspiracy theory; danger of vaccination against Covid-19 for human life and reproductive health; an attempt to establish control over people (chip implantation) with the help of a vaccine (Parmet and Paul, 2020). And if such false news is not confirmed by anything, the dissemination of unreliable statistics on the incidence of Covid-19, which are presented in the form of figures, often leave no doubt, such data is trusted, and they use them if necessary.

Recently, the number of cases of misrepresentation in the field of health care regarding the epidemiological situation, has increased rapidly, which requires national policy to ensure the procedure for prosecution for this dangerous offense. But a logical question arises: can it be a question of criminal liability; are there grounds for criminalizing such an illegal act?

The answer to these questions can be the principles (grounds) of criminalization of illegal acts. There is no single approach to the principles of criminalization of acts in the doctrine of criminal law. However, since this is not the subject of this study, it is not worth delving into the discussion. But there are five main general grounds for criminalizing wrongdoing (see Figure 1).

\begin{tabular}{|c|c|c|c|c|}
\hline & & \multicolumn{3}{|c|}{$\begin{array}{c}\text { Grounds for } \\
\text { criminalization of acts }\end{array}$} \\
\hline $\begin{array}{l}\text { Public danger } \\
\text { posed by an } \\
\text { illegal act }\end{array}$ & $\begin{array}{l}\text { The relative } \\
\text { spread of an } \\
\text { illegal act in a } \\
\text { society that is } \\
\text { socially } \\
\text { dangerous }\end{array}$ & $\begin{array}{l}\text { Changing the } \\
\text { nature of an } \\
\text { illegal act, } \\
\text { which goes } \\
\text { from socially } \\
\text { harmful to } \\
\text { socially } \\
\text { dangerous }\end{array}$ & $\begin{array}{l}\text { Changing the } \\
\text { assessment of } \\
\text { an illegal act } \\
\text { in terms of } \\
\text { values that } \\
\text { are } \\
\text { encroached } \\
\text { upon }\end{array}$ & $\begin{array}{l}\text { The need to } \\
\text { criminalize } \\
\text { the act in } \\
\text { accordance } \\
\text { with the } \\
\text { requirements } \\
\text { of } \\
\text { international } \\
\text { law }\end{array}$ \\
\hline
\end{tabular}

Figure 1. Grounds for criminalization of acts (Dorokhina, 2014).

The main and most important reason for criminalizing the offense is the level of its social danger. Providing inaccurate data on the incidence of pandemics, concealment of information, suppression, falsification of data 
on certain local aspects in the context of the spread of Covid-19 misleads both health workers and ordinary citizens. This, in turn, entails a partial or complete misunderstanding of the situation with morbidity, mortality and danger of this viral disease in general by ordinary people, resulting in a further increase in the incidence of Covid-19. However, if the health care workers rely on inaccurate information about the epidemiological situation, they will simply not be able to react in time and take the necessary measures to stabilize the situation. Therefore, we have a so-called vicious circle, in which the inaccuracy of data leads to failure to take the necessary antiepidemic measures, and their failure in turn contributes to an increase in morbidity, which responsible persons try to hide again by further providing inaccurate information. This is the reason for the public danger of providing inaccurate information about the epidemiological situation in individual regions and in the world in a pandemic, which represents the first ground for criminalizing this act.

The second important reason for criminalization is the spread of the offense. The above data on the ratio of real and official data on the incidence of Covid-19 by individual countries and in general indicates that the information on the incidence rate is at least 3 times lower than the real figures; the Covid-19mortality rate is $60 \%$ higher than the official figures provided by the authorized persons. Unfortunately, even countries with a high level of obedience and legality are also included in the list of countries that provide inaccurate information about the epidemiological situation in their countries. This indicates the widespread negative phenomenon of the falsification of data on Coivd-19 pandemic. This is the second ground for criminalization of acts.

Besides, there are also other grounds for criminalizing illegal acts of providing inaccurate information about the epidemiological situation in a pandemic. In particular, if the dissemination of inaccurate data on a particular disease under normal conditions is only socially harmful and does not pose a serious threat, except for incorrect statistical reporting, in a global pandemic, when there is a threat to human life and health in general, this indicates the existence of such a ground for criminalization as a change in the nature of the assessment of the harmful effects that the dissemination of fake information entails.

At the same time, the attitude towards honesty in providing certain data has changed, regarding the level of morbidity, mortality, and other indicators of the spread of Covid-19, as it has become a value not for each person but for the community as a whole. Accordingly, such a reassessment of the attitude to dishonesty in relation to this type of information determines such a ground for criminalization as a change in the assessment of an illegal act in society. 
The emergence and rapid spread of a new viral disease Covid-19 has become not a national but a global problem. With the rapid increase in the number of people affected by the disease, the international health community has had to respond quickly to this situation and develop special measures to stabilize the health situation in each country. WHO interim recommendations were developed and enshrined in the document entitled Infection Prevention and Control Guidance for Long-Term Care Facilities in the Context of COVID-19 (World Health Organization, 2020). These measures were to be reflected in the national legislation of individual countries. To ensure the effectiveness of these measures, each state must ensure their implementation on the basis of data on the epidemiological situation. And, as mentioned above, the distortion of such data allows implementing the measures specified in the document. That is, there is a fifth ground for criminalizing such an act as providing inaccurate information about the incidence of Covid-19.

The above presupposes not so much the possibility but the urgent need to establish criminal liability for providing inaccurate information in critical conditions, including the epidemics and pandemics. Such a rule may be part of an existing one (if any) in national criminal law, which establishes liability for encroachment on epidemic safety, or a new rule may be created to establish criminal liability for providing inaccurate information on the incidence of the population during an epidemic and/or pandemic.

The rule that should be included in the national criminal law of countries that take all necessary and possible anti-epidemic measures should define actions in the form of providing inaccurate information about the epidemic situation in a pandemic, as well as establish penalties that can be applied to those who committed such act. Given the scale of the impact of providing inaccurate information about the epidemiological situation and the level of morbidity, such an illegal act first of all poses a danger to everyone living in a particular country, and consequently threatens the epidemic security of an individual state. It is the state that is called upon to ensure the safety of citizens and persons staying on its territory on legal grounds, including epidemic security. Human health is the greatest value that the provision of inaccurate data encroaches on, and this illegal act violates the mechanism of state protection of the human right to life, health, and personal safety. Therefore, a rule establishing liability for providing inaccurate information or disseminating inaccurate information on the level of morbidity in an epidemic and/or pandemic should be included in the rules providing for liability for crimes against national security. This socially dangerous illegal act should be punishable by imprisonment for a certain period and, as inaccurate data are usually provided by persons holding relevant management positions in health care facilities - deprivation of the right to hold certain positions and engage in certain types of activities. 
Besides, the right to reliable and complete information in the context of epidemic and/or pandemic and at the international level needs to be guaranteed. Therefore, it is necessary to develop an appropriate international legal act, which will not only indicate the need to prosecute for providing inaccurate information in an epidemic/pandemic, but also to explain why this act should be criminalized and on what grounds. These may be certain Interim Recommendations to ensure the accuracy of information on the epidemiological situation in a pandemic. This document should contain the following provisions:

- Stipulating the importance of obtaining reliable information in the specific conditions of the epidemic/pandemic - obtaining reliable information on morbidity and mortality caused by Covid-19 is a guarantee of timely and necessary measures to stabilize the situation and reduce morbidity.

- Determining the level of public danger of providing inaccurate information about the epidemic situation of Covid-19 - providing inaccurate information about this phenomenon entails failure to take or improper use of necessary anti-epidemic measures, which further increases the incidence and prevents its overcoming.

- Explaining the abundance of inaccurate data on Covd-19 morbidity and mortality - the dissemination of fake information and news and the provision of inaccurate statistics are often carried out by persons holding senior positions in health care institutions and organizations in order to avoid the introduction of anti-epidemic restrictions (in case of data understatement) or obtaining government subsidies to prevent the growth of morbidity (in case of data overstatement).

- Establishment of the main and additional object of illegal provision of inaccurate information about the epidemic situation - this illegal act violates the security in the state, as well as affects the health and lives of people; determination of the type of legal liability and provisions that should contain a rule that will establish liability for providing inaccurate information on the level of morbidity, mortality and epidemic situation in general in the Covid-19 epidemic/ pandemic in particular - given the public danger and abundance of this illegal act, responsibility for it should be provided for in national criminal law by including a rule that will determine the composition of such an act and the punishment for its commission in the form of imprisonment for a certain period and a ban on holding certain positions and engaging in certain professional activities. 


\section{Discussion}

Thus, ensuring the protection of the population from misinformation about the incidence of Covid-19 in a global pandemic is no less important than the practical application of measures taken to stabilize the epidemic situation at the national and, consequently, global level. Ensuring the circulation of reliable information in this situation is almost impossible without taking certain criminal law measures, in particular, bringing to justice for providing inaccurate information about the epidemic situation (Matić Bošković and Nenadić, 2021).

The position on the need to criminalize the provision of inaccurate data on the incidence of Covid-19 in a pandemic is confirmed by the socially dangerous nature of threats to information security created by the dissemination of false news about Covid-19 (Kacper, 2020). If in other conditions distortion of certain data was not considered a crime, in current conditions of epidemic threats even partially reliable data can be considered completely unreliable (Elm and Sarel, 2021). Besides, the so-called infodemic during the Covid-19 pandemic entails significant social changes, including health care, which also requires government intervention and a more severe response to these offenses (Gorbatenko, 2021).

We cannot agree with the statement regarding the national legislation of some states, which do not have criminal liability for providing inaccurate information on any important issue, that their responsibility for misinformation is sufficiently regulated (Prostir.ua, 2020; Olatunji et al., 2020), including misinformation about the epidemic situation. Given the public danger and the abundance of inaccurate data on the incidence of Covid-19, which ultimately entails the impossibility of stabilizing the epidemic situation and overcoming the pandemic, is almost impossible to ensure compliance with the obligation to provide reliable statistics on the incidence of Covid-19 (false news) without the introduction of criminal liability (Kisliy et al., 2021; Bradbury-Jones, 2020; Tereschenko, 2020).

At the same time, we cannot agree that doctors should be protected from liability (including criminal liability) in a pandemic, as this indicates their insecurity before the state (based on a study conducted in Italy) (Ernesto et al., 2020). But it is not advisable to completely eliminate the responsibility of doctors, even during a pandemic, because even in such extreme conditions there are manipulations in the medical field (ALameer et al., 2021; Inshyn et al., 2020), including falsifying data on the incidence of Covid-19. Besides, there is a certain, usually unregulated, medical ethics (Bustan et al., 2021), non-compliance with which cannot be justified even by an epidemic or pandemic.

It should also be borne in mind that some countries are introducing strange practices, establishing responsibility for doubting the reliability 
of official data on the epidemic situation of the incidence of Covid-19, in particular Turkey (Owen, 2020). This position is erroneous because such doubts give rise to the need to revise statistics, which will help to correct errors and more closely monitor diseases, in particular, Covid-19, in terms of developing measures to overcome them (French and Monahan, 2020).

Therefore, the development of the provisions and amendments to national criminal law and relevant international regulations is an appropriate and well-conditioned step in the face of the urgent need to protect the population from the threats posed by the Covid-19 pandemic (Oancea, 2020).

\section{Conclusion}

The problem of criminal liability for providing inaccurate information about the spread of the Covid-19 epidemic in this formulation is raised for the first time. It is established that the national legislation of the countries does not provide for criminal liability for inaccurate information about the epidemic situation in a pandemic. But this illegal act has every reason to be criminalized: it is socially dangerous; quite common in some countries and in the world; the social assessment of misinformation has changed towards increasing condemnation due to the danger posed by the pandemic; the obligation of international organizations to ensure the application of the necessary anti-epidemic measures in the states and their legal enshrinement.

The author is the first to substantiate the need to establish criminal liability for providing inaccurate information about the spread of the Covid-19 epidemic and proposes the wording of the relevant norms. Due to the need to introduce criminal liability for providing inaccurate information at the national level, there is a need to develop the international regulation to clarify the necessity to criminalize this act. This regulation may be Interim Recommendations to ensure the reliability of information about the epidemic situation in a pandemic, which will contain the following provisions:

- stipulating the importance of obtaining accurate information in the specific conditions of the epidemic/pandemic.

- determining the level of public danger of providing inaccurate information about the Covid-19 situation.

- an explanation of the abundance of providing inaccurate data on the incidence of Covid-19 and mortality.

- an indication that this illegal act violates security in the state, as well as encroaches on the health and lives of people. 
- determination of the type of legal liability and the provisions that the norm should contain.

Liability for this act should be provided for in national criminal law by including a rule that will determine the composition of such an act and the penalty for its commission in the form of imprisonment for a certain period and a ban on holding certain positions and engaging in certain professional activities.

The norm that will establish criminal liability for providing inaccurate information or disseminating inaccurate information about the level of morbidity in an epidemic and/or pandemic should be included in the norms providing liability for crimes against national security. The said socially dangerous illegal act should be punished by imprisonment for a definite term and deprivation of the right to hold certain positions and engage in a certain type of activity of persons who provide inaccurate information.

This study is not exhaustive and does not solve all the problems associated with the establishment of criminal liability for providing inaccurate information about the Covid-19 pandemic situation. Instead, the coverage of problematic aspects of the regulation of these aspects of information circulation at the national and international levels opens prospects for further research in this area, which will improve regulatory and practical implementation of criminal law support for reliability of information on the incidence of Covid-19.

\section{Bibliographic References}

ABRUSCI, Elena; DUBBERLEY, Sam; MCGREGOR, Lorna. 2020. An "Infodemic" in the pandemic: Human Rights and Covid-19 Misinformation. Available online. In: http://repository.essex. ac.uk/28053/1/o36.pdf. Consultation date: 09/03/2021.

ALAMEER, Ghaibi Abd; MOSLEM, Dhia; SHEHAD, Ali; ABD, Asseel. 2021. "The Criminal Manipulation in Government Medical Statistics During COVID-19 Crisis: A Comparative Study" In: Indian Journal of Forensic Medicine \& Toxicology, Vol. 15, No. 3, pp. 5415-5420.

ALLAHVERDIPOUR, Herbert. 2020. "Global Challenge of Health Communication: Infodemia in the Coronavirus Disease (COVID-19) Pandemic" In: Journal of Education Community Health. Vol. 7, No. 2, pp. $65-67$.

ASHRAFI-RIZI, Hasan; ZAHRA, Kazempour. 2020. "Information Typology in Coronavirus (COVID-19) Crisis; a Commentary" In: Archives of academic emergency medicine. Vol. 8, No. 1, pp.19-26. 
Andrii A. Danylevskyi, Mykhailo A. Akimov, Vladyslav I. Kutsenko, Oleksandr I. Savka y Tetiana Ye. Leonenko

BANI-ISSA, Husein. 2021. "The criminal liability for the transmission of the Novel COVID-19 to others in accordance with the Bahraini Legislation" In: Analytical Study. Vol. 12, No. 13, pp. 168-176.

BARNERT, Elizabeth; AHALT, Cyrus; WILLIAMS, Brie. 2020. "Prisons: Amplifiers of the COVID-19 Pandemic Hiding in Plain Sight" In: American Journal of Public Health. Vol. 110, pp. 964_966.

BETTINGER-LOPEZAND, Caroline; BRO, Alexandra. 2020. A Double Pandemic: Domestic Violence in the Age of COVID-19. Council on Foreign Relations. Available online. In: https://www.jstor.org/stable/ pdf/resrep29816.pdf. Consultation date: 09/03/2021.

BRADBURY-JONES, Caroline; ISHAM, Louise; NURS, Jon Clin. 2020. The pandemic paradox: The consequences of COVID-19 on domestic violence. Available online. In: https://www.ncbi.nlm.nih.gov/pmc/ articles/PMC7262164/. Consultation date: 25/04/2021.

BRATU, Sofia. 2020. "The Fake News Sociology of COVID-19 Pandemic Fear: Dangerously Inaccurate Beliefs, Emotional Contagion, and Conspiracy Ideation" In: Linguistic and Philosophical Investigations. No.19, pp. 128134 .

BUSTAN, Smadar; NACOTI, Mirco; BOTBOL-BAUM, Katherine; FISCHKOFF, Rita; CHARON, Laure; MADÉ, Jeremy; MEINHARD, Kritzinger. 2021. "COVID 19: Ethical dilemmas in human lives" In: Journal of Evaluation in Clinical Practice. Vol. 27, No. 3, pp.716-732.

CORRIERE DELLA SERA. 2020. Available online. In: https://www.corriere. it/. Consultation date: 09/03/2021.

DATTAA, Rakesh; YADAVB, Alim; SINGHC, Anubhav; DATTAD, Karuna; BANSAL, Ankur. 2020. "The infodemics of COVID-19 amongst healthcare professionals in India" In: Medical Journal Armed Forces India. Vol. 76, No. 3, pp. 276-283.

DOROKHINA, Yulia. 2014. "Analysis of the criminalization and decrimination of malpractice against power" In: Legal Science. No. 6, pp. 76-83.

DW. 2020. "The tip of the iceberg". Is there a real mortality rate from COVID-19 in India? Available online. In: https://www.dw.com/uk/tse-verkhivkaaisberha-yaka-realna-smertnist-vid-covid-19-v-indii/a-57379856. Consultation date: 27/04/2021.

ELM, Jan-Philip; SAREL, Roee. 2021. Partially Right Means Generally Wrong: Why Some COVID-19 Mitigation Strategies Keep on Failing. Available online. In: http://dx.doi.org/10.2139/ssrn.3775020. Consultation date: 23/02/2021. 
ERNESTO D’ALOJA, Gabriele; FINCO, Roberto; DEMONTIS, Pietro; EMANUELE, Napoli; MAURIZIO, Fossarello; MATTEO, Nioi. 2020. "COVID-19 and medical liability: Italy denies the shield to its heroes" In: EClinical Medicine. Vol. 25, p. 100470.

FINANCICAL TIMES. 2020. Global coronavirus death toll could be $60 \%$ higher than reported. Available online. In: https://www.ft.com/ content/6bd88b7d-3386-4543-b2e9-od5c6fac846c. Consultation date: 26/04/2021.

FRECKELTON, Ian. 2020. "COVID-19: Fear, quackery, false representations and the law" In: International Journal of Law and Psychiatry. Vol. 72, No.9, pp.1016-1031.

FRENCH, Martin; MONAHAN, Torin. 2020. "Dis-ease Surveillance: How Might Surveillance Studies Address COVID-19?” In: Surveillance \& Society. Vol. 18, No. 1, pp. 17-28.

FRIEDRICHS, David; VEGH WEIS, Valeria. 2021. "COVID-19 and the U.S. Health Care Industry: Towards a 'Critical Health Criminology' within State Crime Studies” In: State Crime Journal. Vol. 10, No. 1, pp. 126-146.

GLOBAL DATA. 2021. Coronavirus (COVID-19) Dashboard. Available online. In: https://covid19.who.int/who-covid-19-global-data.csv. Consultation date: 09/03/2021.

GORBATENKO, Olga. 2021. "Infodemic as social challenge: international, regional, national settings" In: Proceedings of INTCESS 2021 8th International Conference on Education and Education of Social Sciences, pp. 346-350.

HSDL. 2019. Government Responses to Disinformation on Social Media Government Responses to Disinformation on Social Media Platforms. Report for Congress LL File No. 2019-017919. Available online. In: https://www.hsdl.org. //digitalcommons.unl.edu/scholcom/178/. Consultation date: 20/04/2021.

HURFORD, Beth; RANA, Abhishek; SAMIR KUMAR SACHAN, Rohan. 2021. "Narrative-based misinformation in India about protection against Covid-19: Not just another "moo-point"” In: Indian Journal of Medical Ethics, pp. 21-25.

INSHYN, Mukola; SAINETSKY, Oleh; MELNYK, Volodumur; HUBS'KA, Olha; DZHURA, Kateryna. 2020. "Criminological Assessment of Medical Misconduct during the COVID-19 Pandemic" In: International Journal of Criminology and Sociology. Vol. 9, pp. 2012-2020. 
Andrii A. Danylevskyi, Mykhailo A. Akimov, Vladyslav I. Kutsenko, Oleksandr I. Savka y Tetiana Ye. Leonenko

INTERFAX. 2020. The actual number of COVID-19 cases in Ukraine is about 185 thousand against 55 thousand officially confirmed - KSE. Available online. In: https://ua.interfax.com.ua/news/general/674927.html. Consultation date: 12/03/2021.

KACPER, Gradoń. 2020. "Crime in the time of the plague: fake news pandemic and the challenges to law-enforcement and intelligence community" In: Society Register. Vol. 4, No. 2, pp. 133-148.

KISLIY, Anatoliy M; KYSLENKO, Dmytro P; TYMOSHENKO, Yuriy P; KALININA, Iryna V; HURINA, Dariia P. 2021. "Criminal provision of medical secret protection in Covid-2019" In: Ad Alta Journal of Interdisciplinary Research. Vol. 1, special issue 26, pp. 67-71.

KOVALEVA, Natalia; ANICHKIN, Svatoslav; ANISIMOVA, Alina. 2020. "Legal Aspects of Information Threats in the Form of "Fakes" in the Conditions of Spread of COVID-19" In: Advances in Social Science, Education and Humanities Research. Vol. 48, pp. 222-226.

KOVALOVA, Svitlana. 2021. "Responsibility for violation of quarantine and sanitary rules and regulations for the prevention of the spread of coronavirus infection (COVID-19) under the laws of foreign countries and Ukraine” In: Right, Man, Environment. Vol. 12, No. 1, pp. 112-129.

LI, Hao; HU, Mengnan; LIU, Shuang. 2020. "The need to improve the laws and regulations relevant to the outbreak of COVID-19: What might be learned from China?" In: Journal of global health. Vol. 10, No. 1, pp. 328339 .

MAHESHWARI, Mudit; GAUTAM, Hardik. 2021. Breach of right to life during covid-19 era: fixing government's liability to compensate. Available online. In: https://thedailyguardian.com/breach-of-right-to-life-duringcovid-19-era-fixing-governments-liability-to-compensate/. Consultation date: 09/03/2021.

MATIĆ BOŠKOVIĆ, Marina; NENADIĆ, Svetlana. 2021. "Impact of covid-19 pandemic on criminal justice systems accross Europe" In: EU and Comparative Law Issues and Challenges Series (ECLIC). Vol. 5, pp. 263290.

MINFIN. 2021. Coronavirus: country statistics. Available online. In: https:// index.minfin.com.ua/reference/coronavirus/geography/WHO. Consultation date: 09/03/2021.

OANCEA, Clara Maria. 2020. "Amendment of Criminal Legislation in the Context of the Current Covid-19 Coronavirus Pandemic" In: Proceedings of the 17th International RAIS Conference on Social Sciences and Humanities, pp. 108-112. 
OLATUNJI, Olusoji; AYANDELE, Olusola; ASHIRUDEEN, Doyin; OLUWATOSIN, Olaniru. 2020. “"Infodemic” in a pandemic: COVID-19 conspiracy theories in an african country" In: Social Health Behavior. Vol. 3, pp. 152-157.

OWEN, Dyer. 2020."Covid-19: Turkey cracks down on doctors who doubt official figures” In: British Medical Journal. Vol. 370, pp. 26-29.

PARMET, Wendy; PAUL, Jeremy. 2020. "COVID-19: The First Posttruth Pandemic" In: American Journal of Public Health. Vol. 110, No. 7, pp. 945-946.

PROSTIR.UA. 2020. Ukraine already has legislation and mechanisms to combat misinformation: why the fight? Available online. In: https://www.prostir. ua/?news=v-ukrajini-vzhe-je-zakonodavstvo-i-mehanizmy-schodoprotydiji-dezinformatsiji-zarady-choho-kolotnecha. Consultation date: 24/04/2021.

QUINTANA, Francisco-José; URIBURU, Justina. 2020. "Modest International Law: COVID-19, International Legal Responses, and Depoliticization" In: American Journal of International Law. Vol. 114, No. 4, pp. 687-697.

RADU, Roxada. 2020. Fighting the 'Infodemic': Legal Responses to COVID-19 Disinformation. Available online. In: https://journals.sagepub.com/ doi/full/10.1177/2056305120948190. Consultation date: 09/03/2021.

RAJAT, Khosla. 2020. "Technology, Health, and Human Rights: A Cautionary Tale for the Post-Pandemic World" In: Health and Human Rights. Vol. 22, No. 2, pp. 63-66.

ROGER LU, Philips; LAYLA, Abi-Falah. 2020. "Criminal Responsibility for the COVID-19 Pandemic in Syria” In: Columbia Human Rights Law Review, p. 523 .

TERESCHENKO, Lidia. 2020. "Fake News: Legislation and Judicial Practice" In: Legal Issues in the Digital Age. Vol. 3, No. 3, pp. 140-147.

WORLD HEALTH ORGANIZATION. 2020. Infection prevention and control guidance for long-term care facilities in the context of COVID-19: interim guidance. Available online. In: https://apps. who.int/iris/handle/10665/331508. https://heinonline.org/HOL/ LandingPage?handle=hein.journals/tsinghua12\&div=23\&id=\&page $=$. Consultation date: 21/04/2021.

WORLDOMETERS. 2021. Coronavirus Worldwide Graphs. Available online. In: https://www.worldometers.info/coronavirus/. Consultation date: 09/04/2021. 
Andrii A. Danylevskyi, Mykhailo A. Akimov, Vladyslav I. Kutsenko, Oleksandr I. Savka y Tetiana Ye. Leonenko

266 Criminal Liability for Providing Inaccurate Information about the Spread of the COVID-19 Epidemic

YIRONG, Sun. 2021. "From SARS to COVID-19: Balance of China's Criminal Law System” In: Tsinghua China Law Review, p. 399.

ZDRAV.EXPERT. 2021. Morbidity and mortality from coronavirus COVID-19. Available online. In: https://zdrav.expert/index. 
Vol. 39 N $^{\circ} 71$

Esta revista fue editada en formato digital y publicada en diciembre de 2021, por el Fondo Editorial Serbiluz, Universidad del Zulia. Maracaibo-Venezuela 